\title{
弘前市仲町地区における歴史的 A SURVEY OF ENVIRONMENTAL 町並みの環境管理の実態調査 \\ MANAGEMENT FOR HISTORIC PRESERVATION DISTRICT IN NAKACHO, HIROSAKI
}

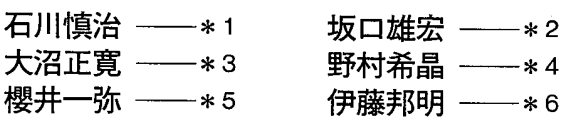

キーワード :

環境管理, 住民意識, 伝建地区, 仲町地区

Keywords :

Environmental management, Residents' opinion, Historic district, Nakacho district

\author{
Shinji ISHIKAWA - * 1 \\ Masahiro ONUMA - *3 \\ Kazuya SAKURAI —* 5
}

The results of a survey of environmental management for Nakacho historic preservation district have been described. There is interrelation among rearrangement of scenery, maintenance, and learning environmental information. It is necessary to provide continuous opotunities for understanding the system of the historic district in order to make environmental management active without interruption. In Nakacho district, it is important not only to reconstruct the standards of the preservation plan but also to support the resident's activity.
1 はじめに

1960年代から顕著となった我が国経済の高度成長等の社会経済状 況の大きな変動の中で、歴史的集落や町並みが急速に失われていく 危機的状況に対して1970年前後から長野県南木曽町妻籠や金沢、倉 敷、高山、萩などで集落・町並みの保存事業が始まった1)。その後 の伝統的建造物群保存地区制度や様々な景観条例などにより、現在 では建物や緑といった歴史的景観を構成する「もの」の保存につい ては共通認識となってきた。しかし、歴史的町並みは地域の遺産で ある「もの」と町並みの環境を管理する「ひと」がいて初めて成り 立つものである。歴史的町並みの環境管理における建造物などの規 制の必要性は共通理解を得ているが、維持管理についての重要性は 最近ようやく認識され始めた感がある。

本報では、伝統的建造物群保存地区制度（以下、「伝建制度」）の 創始期に国の選定を受けた青森県弘前市仲町重要伝統的建造物群保 存地区（以下、「仲町地区」）を事例とし、1. 環境管理についての現 状のまとめ、2. 歴史的町並みの環境管理に対する実態調査、3. 今後 の課題の整理を報告する。

\section{2 仲町地区の概要}

仲町地区は弘前市の中心部に位置し、かつては津軽藩の中下級武
士の住宅地であった(図 1)。仲町地区は他の歷史的町並みとは違つ て伝統的建造物が少ない（写真 1)。しかし、樹木・サワラなどの生 垣・庭園等の屋外環境がよく残り（写真 2 )、地区住民の手により藩 政期の面影を保ってきていた ${ }^{2)}$ 。昭和 53 年に「伝統的建造物群及び 地割がよく旧態を保持しているもの」という理由で国から重要伝統 的建造物群保存地区に選定された (表 1 )。近年、生活様式の变化や 財産相続などによる敷地分割が地区の景観に影響を及ぼしてきてい る。平成 $12 \cdot 13$ 年度には伝建見直し調查が行われ、今後の仲町地区 のあり方を見つめ直す時期に来ているところである。

\section{3 環境管理について}

仲町地区における町並みの「環境管理」を「身の回りの環境に対 して伝統的な景観を尊重しつつ、良質な住環境を実現させるための 行為」と定義した。さらに「環境管理」は、地区の景観要素を整え るための「修理・修景」おもに屋外環境の手入れなど歴史的空間を 整えるための「環境維持」、地区の人々の意識を高める「教育」の三 つで構成されている（図2）。なかでも仲町地区において特に重要な ものとして一つは修景であり、もう一つは生垣などの維持管理であ る。ここで挙げた二つの環境管理の活動が仲町の町並みを支えてい るが、その実現には自分達が住む歴史的な町並みに対する誇りと歴

表 1 仲町地区の概要

\begin{tabular}{|l|c|c|c|c|c|c|c|}
\hline \multicolumn{1}{|c|}{ 所在地 } & 選定年月日 & 地区面皘 & 建築物 & 工作物 環境物件 & 人口(H13.3現在) & 世帯数(H13.3現在) \\
\hline $\begin{array}{l}\text { 青森県弘前市大字馬喰町の全部,若党町， } \\
\text { 小人町の各一部 }\end{array}$ & 昭和53年5月31日 & 約10.6ha & 30 & 5 & 81 & $522 人$ & 238 \\
\hline
\end{tabular}

*1 東北大学大学院工学研究科都市 - 建築学専攻 博士後期課程 工工修 （干980-8579 仙台市青葉区荒巻字青葉06)

*2 (侏)大林組 工修

*3 東北文化学園大学科学技術学部環境計画工学科 助手 ·工修

*4 東北大学大学院工学研究科都市 ·建築学專攻 助教授 . 工博

*5 東北大学大学院工学研究科都市 · 建築学専攻 助手 · 工修

*6 東北大学大学院工学研究科都市・建築学専攻 教授 ·工博
*1 Graduate School, Tohoku University, M. Eng.

*2 Obayashi Corporation, M. Eng.

*3 Res. Assistant, Dept. of Environmental Planning Technology, Tohoku Bunka Gakuen Univ., M. Eng.

*4 Assoc. Prof., Graduate School of Engineering, Tohoku University, Dr. Eng.

*5 Res. Assistant, Graduate School of Engineering, Tohoku University, M. Eng.

*6 Prof., Graduate School of Engineering, Tohoku University, Dr. Eng. 


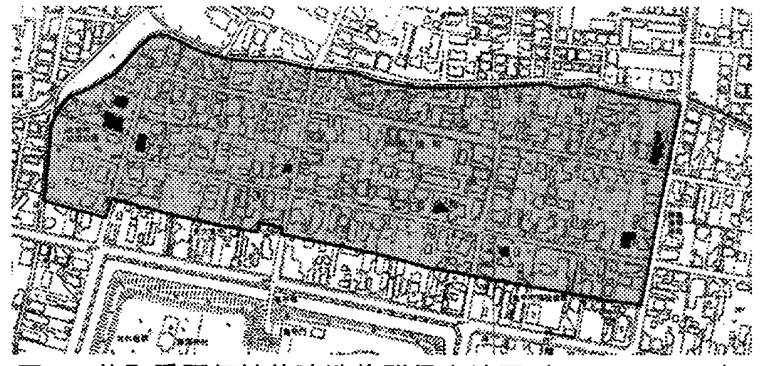

図 1 仲町重要伝統的建造物群保存地区 (scale:1/5000)

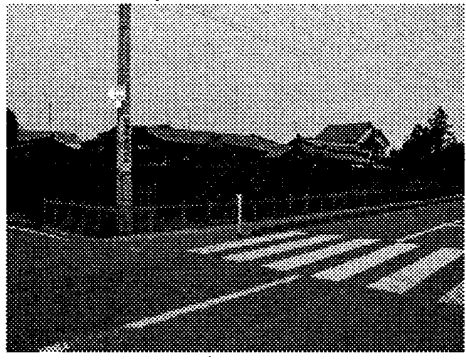

写真 1 伝統的建造物

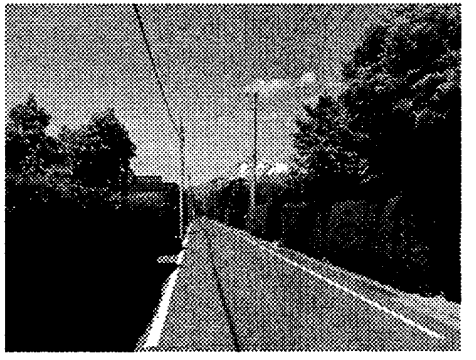

写真 2 サワラ垣の町並み

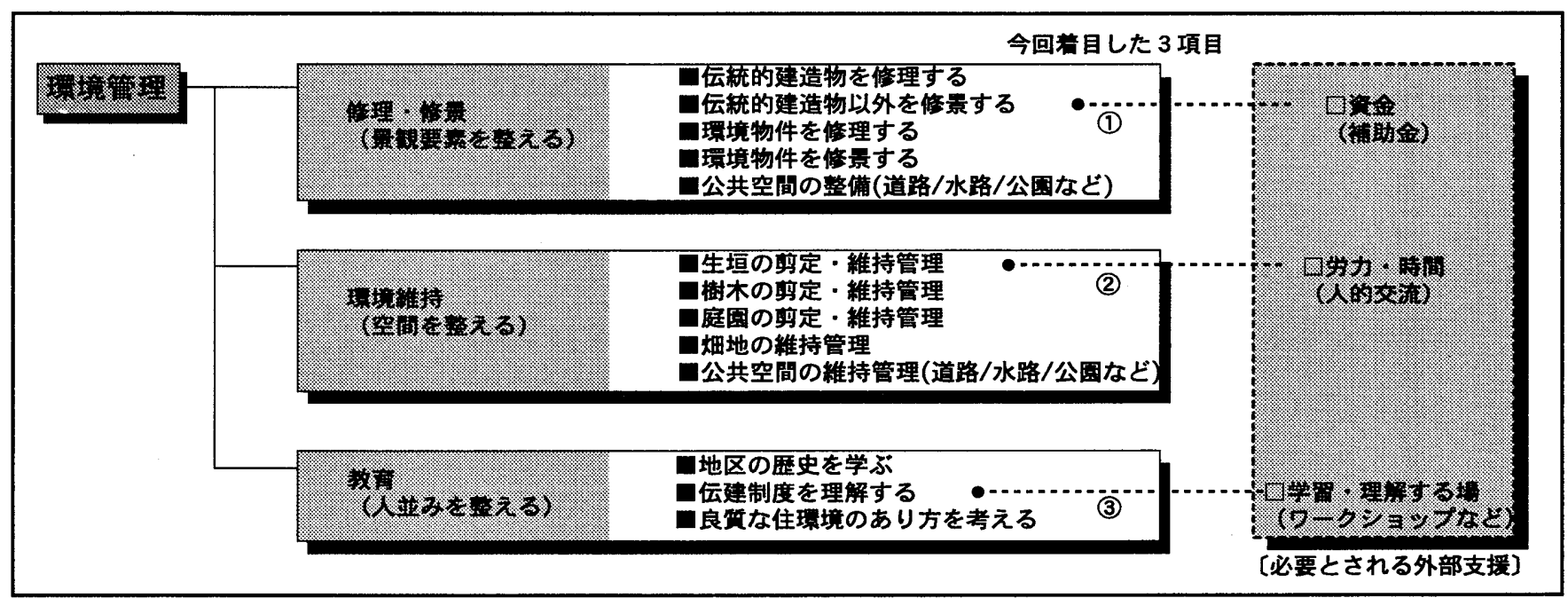

図 2 歴史的町並みの環境管理モデル（仲町地区）

史的町並みを有している地域の人々の評価と理解があってこそのも のであると考えられる。

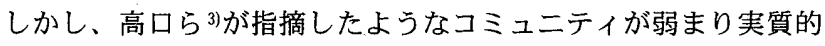
に個々の市民対自治体という近代的な関係を基本として制度が運用 されている大都市自治体の中にある伝建地区に仲町地区は分類され る。そのため、ここで定義されている「環境管理」の活動は住民の 努力だけでは困難な状態にあり、外部からの支援が必要となる場合 が多い。ここで上げた三点に着目してみると、修景では通常の住宅 地で住宅を建てる場合よりも多く資金が必要となってくるであろう し、維持管理では建造物とは違い、時間的に短い間隔で手入れする 必要があり時間と労力が求められる。また、町並みや伝建制度に対 する理解は、常に町並みについての情報を受けたり、学習する場の 提供によって学んでいくことが必要であると思われる。一般に伝建 地区のような歴史的町並みでは保存計画といつたハード整備事業だ けではなく:このようなりフト支援が必要不可欠になってきている。 仲町地区において地区のシンボルでもあるサワラ垣の維持管理が地 区住民の高齢化により徐々に維持が困難なものとなっている。本来 であれば隣人による協力といった人的支援が考えられるが、実際は 補助金などによって労力を補っている。修景についても伝建制度創 始期に選定された地区なので基準に不十分な点があり、補助金額に ついても十分であるとはいえない。また選定から四半世紀が経とう としている現在、人の入れ替わりの激しい地区であるにもかかわら ず、伝建地区における理解を深めるような場が少ないため、地区選 定後に転入してくる住民には伝建制度が浸透していないように見受 けられる。このように「環境管理」に対する支援が十分とはいえず、 この点も 2 度目の見直し調査が行われることになった要因だと考え
られる。

ここで挙げた主な三つの視点から仲町地区における「環境管理」 の実態をアンケートにより把握し、歴史的町並みにおける「環境管 理」の今後について考えることとする。

\section{4 意識調查の方法}

本調査では仲町地区の住民（以下、「地区住民」）と仲町地区に居 住していない弘前市民（以下、「弘前市民」）を対象とした。地区住 民については「保存意識」と「町並み環境維持の塞態」、弘前市民に ついては「保存意識」をアンケートで調査することとした。

地区住民に対しての調査は、仲町地区内の世帯主を対象に平成13 年 12 月 9 日から 12 月 26 日にかけて実施した。調査票の配布・回収 は町会の協力を得て留置調査とした。居住者の入れ替わりが激しい と思われるアパート等は今回のアンケートの対象からはずした。ア ンケートの配布枚数は 189 世帯、回答数は 109 世帯で回収率は 57.6 \%であった。

また、弘前市民に対しての調査は、平成 13 年 9 月 10 日から 10 月 20 日にかけて郵送調查により実施した。調查対象者は、選挙人名簿 から無作為抽出により抽出された 20 歳以上の弘前市民1271名とし た。アンケートの有効な回答者数は 263 名 $(20.7 \%)$ であった。

\section{5 地区住民の現況、環境維持の実態}

アンケートに回答した世帯主は $60 \sim 70$ 歳代が多く、全体の約 50 \%を占めていた。因みに、仲町地区の高齢化率は $30.1 \%$ (H13.3 現在) と高く、地区での環境管理の実施者が高齢化していることが分かる。 また、後継者の有無の設問では地区内の同居の割合が小さく、特に 


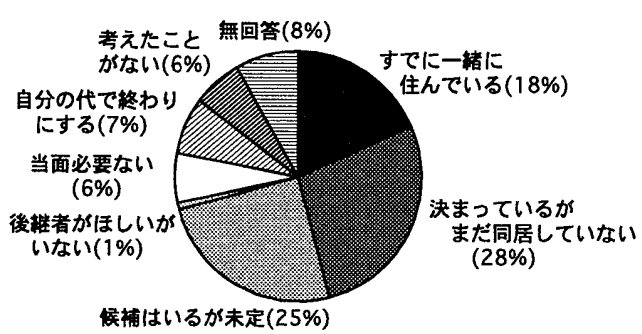

図 3 後継者の有無

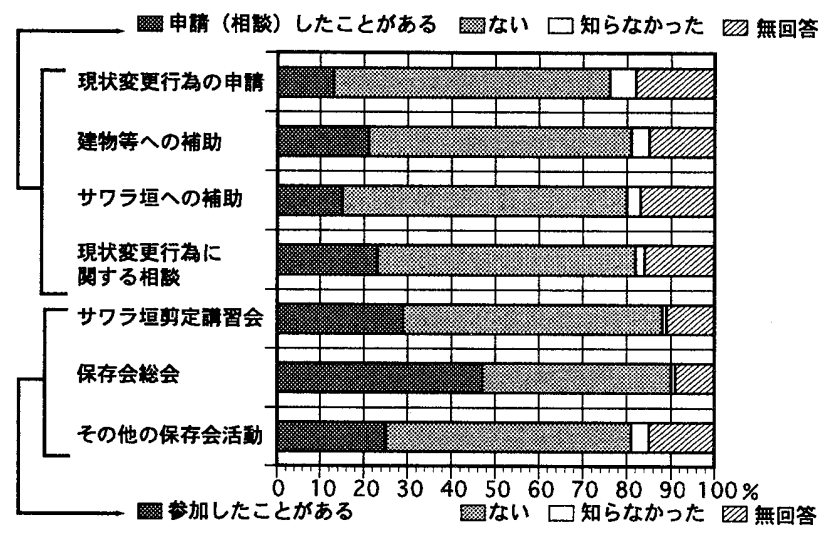

図 4 保存活動と地区住民の関わり

維持管理に必要な労力が不足していることが分かる（図 3)。 仲町地区の環境管理に関わる活動に関わつたことがあるかについ て尋ねた結果が図 4 である。「環境管理に関わる活動」とは、現状 変更行為・修景事業・現状変更行為に関する相談・保存会の活動と 定義した。これらの活動に関わったことのある回答者は65\%となっ ている。「現状変更行為の申請」・「建物などへの補助の申請」・「午 ワラ垣への補助金申請」・「現状変更行為の相談」には相互に関連 があり、現状変更行為などの申請を行った住民は他の補助金制度な ども利用するが、申請したことがない住民はまったくしないでいる という顕著な傾向が見られた。また、図5の結果を見ると発行物 (パ ンフレットなど)から伝建制度について情報を得る地区住民は環境 管理について他人任せにする割合が他の情報源よりも大きいことが 分かる。このことから、環境維持を行う前提条件である町並みへの 理解が環境管理における活動への影響が大きいと考えられる。

つぎに仲町地区において環境管理の中でも積極的に行われている と思われるサワラ垣と樹木の手入れについて尋ねた結果が図 6 であ る。サワラ垣の手入れは $30 \%$ 人が自分で行い、半数近くの人が業 者などに手入れを頼んでいる。庭の手入れに関しても $30 \%$ 超える 人が業者に手入れを頼んでいる。サワラ垣の維持管理に対する不安 とサワラ垣に対する補助金申請の関係については図 7 の結果となつ た。維持管理における不安の主な要因は経済的な負担であった。ま た、経済的な不安を感じながら補助金申請を行ったことがない人が 多いことがわかり、ここでも制度が住民に十分に理解されていない ことがわかる。また、他人に手入れを頼む場合、誰に頼むかを尋ね たところ、ほぼ全員が業者に頼むと答えている。かつて、サワラ垣 や庭の手入れのために親族や知人が手伝いにきたということは現在

\begin{tabular}{|c|c|c|c|c|c|}
\hline & 行政の担当者 & 保存会の方 & 近所の方 & 発行物 & 教計 \\
\hline 搷楆的に参加 & 1 & 1 & 0 & 1 & 3 \\
\hline やれることを自分な & 14 & 9 & 2 & 16 & 41 \\
\hline 他人に任せてきた & 1 & 5 & 0 & 18 & 24 \\
\hline $\begin{array}{l}\text { 自分は閣係ないた } \\
\text { と思っていた }\end{array}$ & 1 & 0 & 2 & S & 8 \\
\hline 松計 & 17 & 15 & 4 & 40 & 76 \\
\hline
\end{tabular}

図 5 環境管理活動への参加と制度の説明者

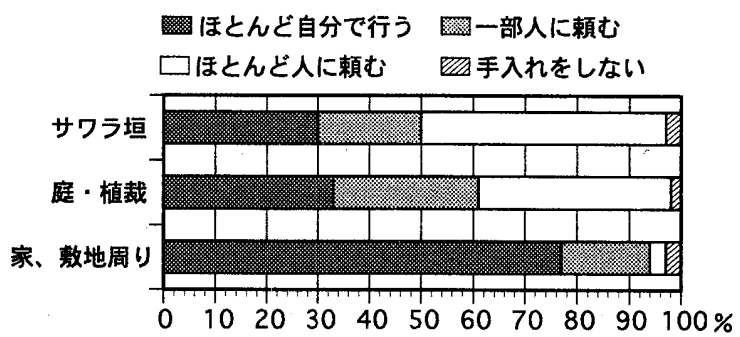

図 6

サワラ垣・庭木・家の周囲の手入れ

\begin{tabular}{|c|c|c|c|c|}
\hline & $\begin{array}{c}\text { 申吾したこと } \\
\text { がある }\end{array}$ & ない & 知らなかった & 総 竍 \\
\hline 程済的な負担 & 13 & 24 & 1 & 38 \\
\hline 労 カ & 13 & 8 & 1 & 22 \\
\hline 技街 - 知䤒の不足 & 2 & 9 & 0 & 11 \\
\hline 近隣とのトラブル & 0 & 4 & 0 & 4 \\
\hline その他 & 1 & 2 & 0 & 3. \\
\hline 総 尌 & 29 & 47 & 2 & 78 \\
\hline
\end{tabular}

図 7 維持管理に対する不安と補助金申請（サワラ垣）

ではもはや見かけられなくなったということであろう。これも環境 維持の支援が労力から補助金に変わった結果であると思われる。

伝建制度によるプラス効果・マイナス効果についてそれぞれ聞い た結果は図 8、9である。プラス効果については「良い住環境が残

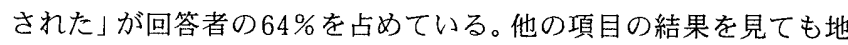
区住民は歴史的景観の保存に伝建制度が効果があったと考えてい る。しかし、歴史的景観の保存による相乗的な効果についてはあま り高い值とはいえない。マイナス効果をみると、制度自体が分かり にくいという内容が多く目につく。現在の保存計画における地区の 保存の基準・現状変更行為に対する基準が曖昧なことが関係してい ると思われる。そのため、指定されない方が良かったと思っている 人のほとんどが現状変更行為に対する規制に疑問をもっている。ま た、伝建制度の内容について知っている人の 4 割強の住民が配布さ れたパンフレットで知ったということであった（図 10）。地区住民 は毎年、現状変更行為等の申請をするわけではない。よって伝建地 区選定後に転入してきた住民のことを考えると、「仲町地区でなぜ 伝建制度なのか」という根本的な部分の理解には至らないと思われ る。

このように見ていくと、伸町地区の環境整備のための指針ともい える保存計画等の制度上の不備に加え、環境管理活動の前提条件で ある住民が仲町地区を理解するための場が少ないことが分かる。最 近は途絶えていたサワラ垣の剪定講習会が復活したり、仲町地区周 辺の子供達による樹木の名札づくりなどの活動が開かれてきてはい るが、現在のままでは十分だとは言い難い。この三つの視点には関 連性があり、ソフト支援の充実がハードの整備にまで影響を及ぼす ことも分かった。 

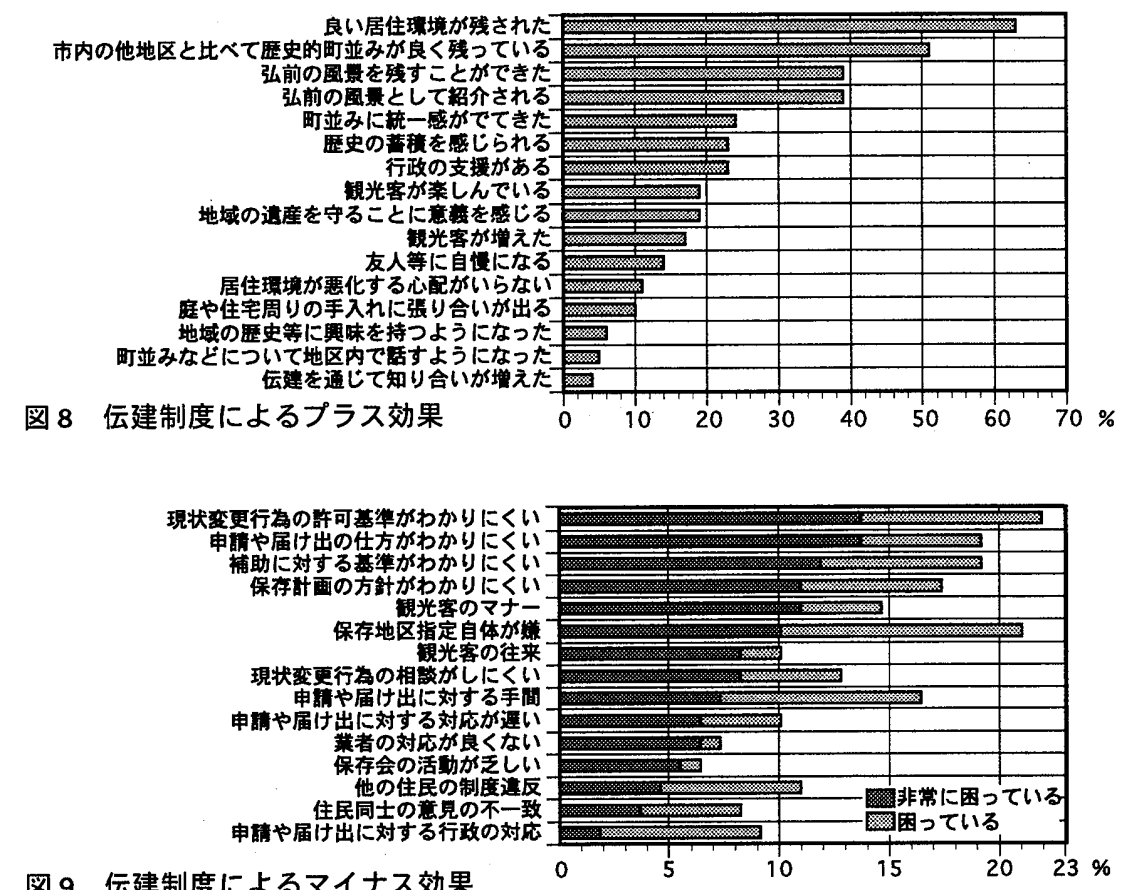

図 9 伝建制度によるマイナス効果

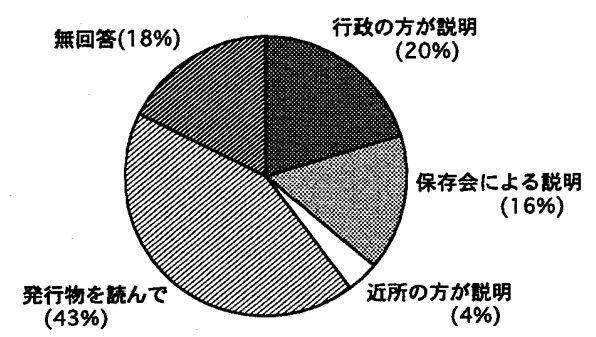

図 10 伝建制度についての情報源

\section{6 弘前市民（回答者）の現況、保存意識}

アンケートで回答された世帯主の年代は $40 \sim 50$ 歳代が多く見ら れ、世帯人員は2 4 人が多かった。因みに弘前市の人口は 177086 人、世帯数は64091戸（H13.3 現在）となっている。

まず、仲町地区を知っているか、また何回ほど訪れたことがある のかを尋ねたところ、回答者の $80 \%$ の人が仲町地区を知っており （図11）、70\%を超える人が訪れたことがあると答えている(図12)。 住民のプライバシーを守るためにこれまで対外的な宣伝をあまりし てこなかったことから考えると大きな数值であることが分かる。一 般的に弘前市民全体の財産と考えられる仲町地区であるが、回答者 が仲町の歴史景観をどのように評価しているかを聞いた(図13)。仲 町地区の歴史的景観の評価については $75 \%$ の人が残っていると答 え、残っていないと答えた人は $5 \%$ ほどであり、これまでの睘境整 備事業についての評価は得られている。これは歴史的町並みの保存 に伝建制度のような規制を伴う制度が必要かを尋权た設問で $76 \% の$ 人が必要と考えていることからも分かる（図 14）。そして今後も仲 町地区の歴史的景観を残していきたいと $83 \%$ の回答者が回答してお り（図 15）、仲町が弘前市にとって重要な位置を占めていることが 分かる。

\section{7 まとめ}

弘前市仲町地区の歴史的町並みの環境管理についての調査結果か ら以下のことが明らかになった。(1)伝建制度への理解の大小が環境

\section{謝辞} 上げます。

\section{参孝文献}

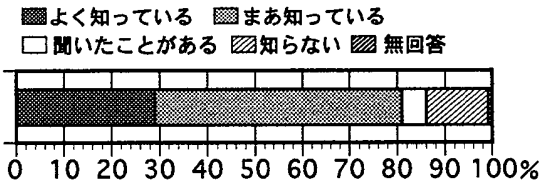

図 11 仲町地区の認知

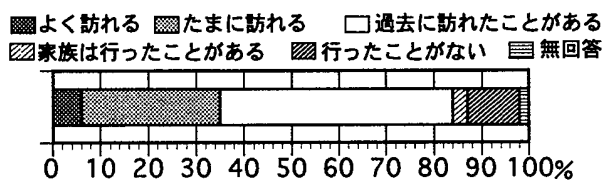

図 12 仲町地区への来訪頻度
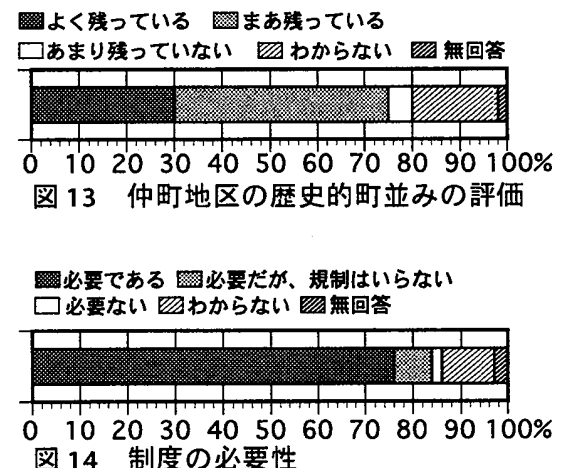

図 14 制度の必要性

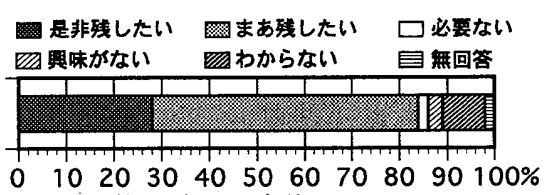

図 15 仲町地区の今後

管理活動への参加・不参加に大きく影響している、(2)維持管理のた めの労力不足を人的交流ではなく補助金交付で対処しているが故に 地区住民に経済的な不安が残っている、(3)地区住民と弘前市民の間 では伝建地区に対する認識が大きく異なるの三点である。このこと から環境管理モデル（図 2）の三つの要素の関倸性が明らかになつ た。歴史的町並みの環境管理においては八ード的整備と同じくらい ソフト面での支援が必要である。地区住民は、行政、地元の住民組 織、学術機関やNPOなどと連携しながら歴史的町並みに対する理解 を深めて環境管理をおこなうべきであると考えられる。

本報は財団法人大林都市研究振興財団の助成を受けました。厚く御礼申し

1)大河直躬編 : 歴史的遺産の保存・活用とまちづくり，学芸出版社,1997 2)弘前市・弘前市教育委員会: 弘前の町並 (武家屋敷) - 伝統的建造物群保存 地区保存調查報告書 -, 1977

3) 高口愛,西村德明: 伝統的景観管理とその変遷〜竹富島集落における景観管 理能力の発展条件に関する研究 その1〜,日本建築学会計画系論文集第 538 号,pp.133-140,2000年12月

4)西村徳明、三村浩史：伝統的建造物群保存地区における景観管理計画に関 する研究〜白川村荻町合掌集落を事例として〜,日本建築学会計画系論文集 第 474 号,pp.133-141,1995年 8 月

5)弘前市・弘前市教育委員会 : 弘前の町並（II 仲町地区の住戸現況と修景計 画）-伝統的建造物群保存地区保存調査報告書 - , 1978

6)福武直 : 社会調查補訂版, 岩波全書, 1997

[2002年 4 月19日原稿受理 2002年 7 月23日採用決定］ 